
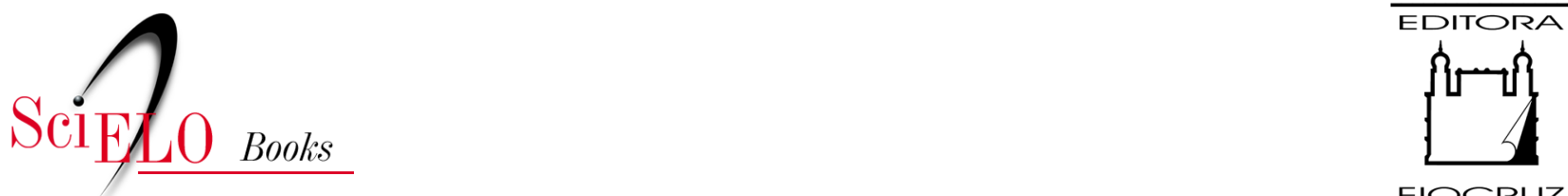

FIOCRUZ

\title{
Noções de imunologia sistema imunológico, imunidade e imunização
}

\author{
Andréia Rodrigues Gonçalves Ayres
}

\section{SciELO Books / SciELO Livros / SciELO Libros}

AYRES, A.R.G. Noções de imunologia: sistema imunológico, imunidade e imunização. In: SILVA, M.N., FLAUZINO, R.F., GONDIM, G.M.M., eds. Rede de frio: fundamentos para a compreensão do trabalho [online]. Rio de Janeiro: Editora FIOCRUZ, 2017, pp. 239-256. ISBN: 978-65-5708-091-7. https://doi.org/10.7476/9786557080917.0011.

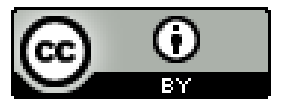

All the contents of this work, except where otherwise noted, is licensed under a Creative Commons Attribution 4.0 International license.

Todo o conteúdo deste trabalho, exceto quando houver ressalva, é publicado sob a licença Creative Commons Atribição 4.0.

Todo el contenido de esta obra, excepto donde se indique lo contrario, está bajo licencia de la licencia Creative Commons Reconocimento 4.0. 


\section{Noções de imunologia: sistema imunológico, imunidade e imunização}

Andréia Rodrigues Gonçalves Ayres

A história da descoberta das vacinas mostra que os médicos e pesquisadores envolvidos apostavam numa proteção cuja base e cujos mecanismos não conheciam. Foi com o avanço dos estudos e das tecnologias disponíveis para a produção científica que os mecanismos de resposta imunológica às infecções e da imunidade foram desvendados.

Como trabalhador da rede de frio de imunobiológicos, é importante conhecer, em linhas gerais, quais efeitos as vacinas são capazes de desencadear no organismo do indivíduo e como o indivíduo se torna imunizado. A compreensão do funcionamento desse sistema é fundamental como objeto de seu trabalho. Por isso, neste capítulo, apresentaremos, brevemente, de que forma o nosso organismo reage frente à presença do antígeno, a ação do sistema de proteção e como nos tornamos imunes a determinadas doenças através da administração dos imunobiológicos.

\section{Imunidade, componentes e mecanismos de ação}

O termo imunidade é derivado do latim immunitas, que se refere às isenções de taxas oferecidas aos senadores romanos (Unicamp, 2016). Historicamente, imunidade representa proteção a doenças, mais especificamente, doenças infecciosas. A imunidade pode ser basicamente entendida como a capacidade do organismo de se defender contra a entrada e multiplicação de microrganismos. É uma função biológica que envolve uma série de componentes que atuam de forma coordenada (o sistema imunológico) e que é estudada pela imunologia. 
A imunologia é uma disciplina que se relaciona a outras na tentativa de esclarecer os mecanismos envolvidos no desenvolvimento de doenças. Com a microbiologia, ciência que estuda formas de vidas microscópicas (tais como bactérias, fungos e vírus) e suas interações com humanos, essa relação se destaca, ao estar interligada ao processo de imunização, como veremos.

A compreensão e o conhecimento sobre o sistema imunológico, sua estrutura, seu desenvolvimento, as respostas imunológicas e a função desempenhada por cada célula na defesa do corpo humano são processos que vêm se construindo ao longo do tempo. Avanços importantes foram alcançados a partir do aprimoramento nas áreas da microbiologia, da histologia (ciência que estuda os tecidos biológicos) e do desenvolvimento de microscópios, tecnologia que permitiu visualizar os microrganismos, os tecidos e os mecanismos de ação e reação.
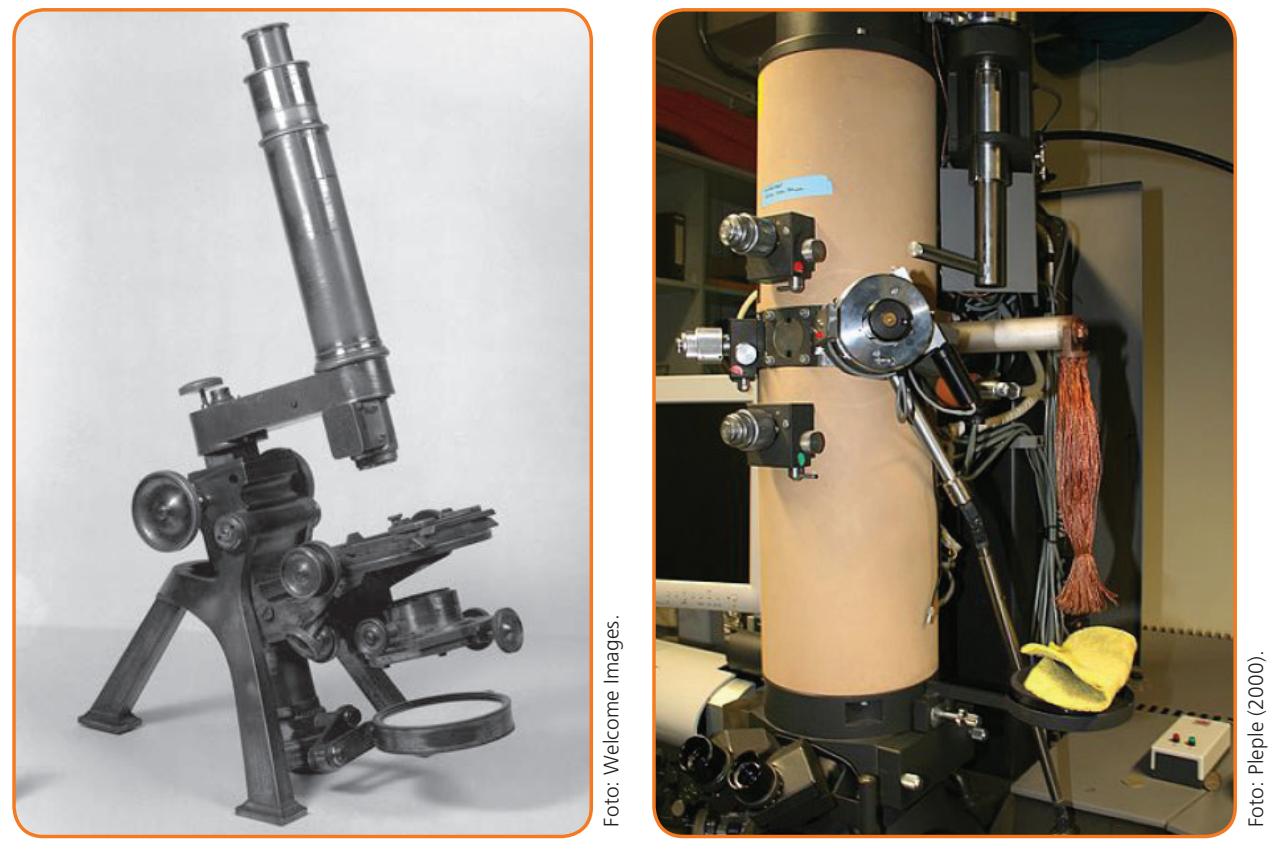

Os microscópios começaram a ser desenvolvidos na Europa, a partir do século XVII, e aumentavam as amostras em até 20 vezes. A evolução das tecnologias em microscopia demandou que esse pequeno equipamento aumentasse de tamanho, ocupando por vezes salas inteiras. Agora, eles podem utilizar feixe de elétrons, fluorescência, entre outros recursos; possibilitam varrer a superfície das amostras ou visualizar o seu interior, conhecendo-se a estrutura de bactérias, vírus, fungos, células (incluindo as do sistema imunológico) etc. Dependendo do microscópio, o aumento das amostras observadas pode chegar a 280 mil vezes!

Fonte: Wikimedia Commons.

A imunidade consiste de um conjunto de processos inespecíficos e específicos. Há barreiras físicas e químicas que visam impedir a entrada de microrganismos patogênicos no organismo. Quando essas barreiras são transpostas, ocorre a infecção do indivíduo. De imediato, a imuni- 
dade limita a ação do invasor e, ainda, cria uma memória imunológica que impede novas infecções pelo mesmo patógeno. A seguir, detalharemos mais essas barreiras.

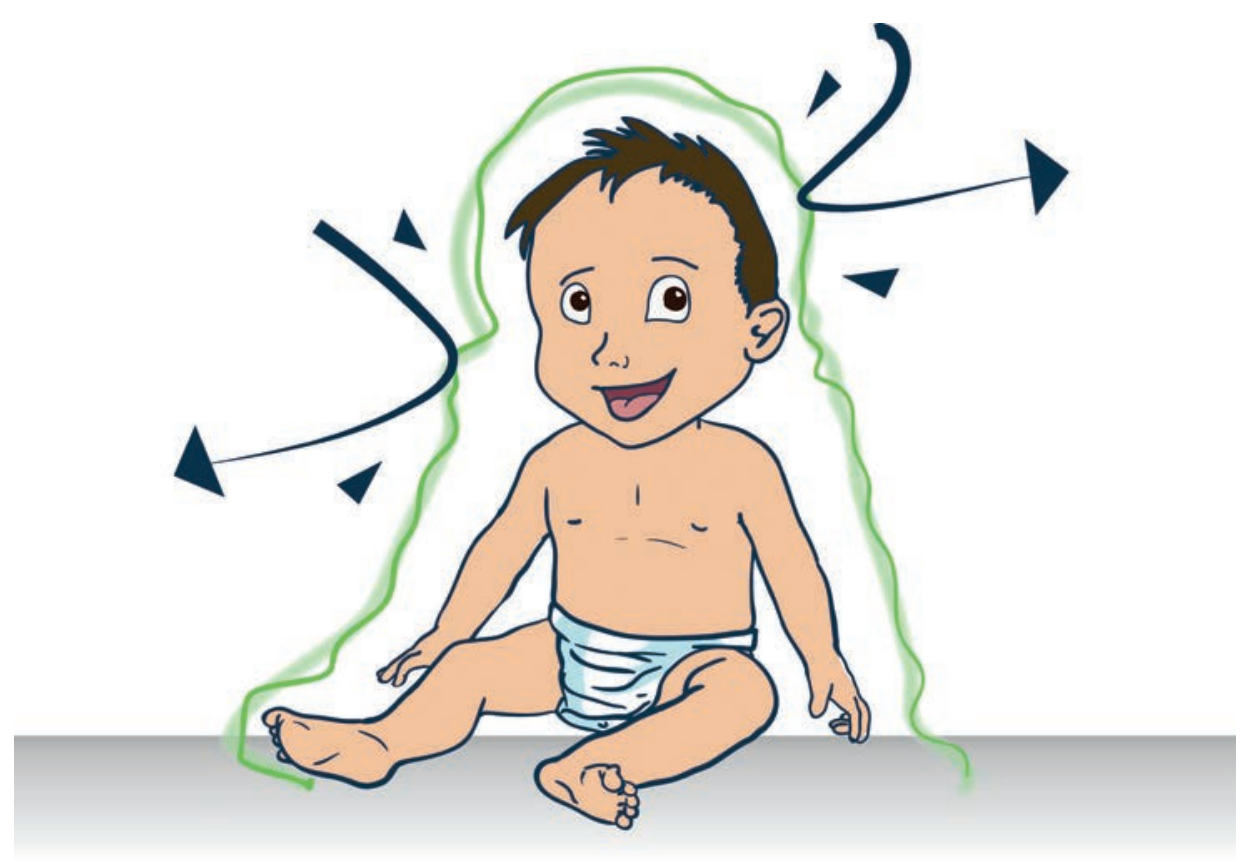

\section{As barreiras inespecíficas}

São chamadas inespecíficas as barreiras desencadeadas independentemente do microrganismo ou do tipo de agressão, ou mesmo sem agressão alguma. Muitas são as funções executadas pelo corpo, diariamente, sem que se pense na sua importância imunológica. A barreira mais óbvia é a pele, que delimita nosso espaço corporal no ambiente, ou seja, delimita o que está dentro e o que está fora do nosso corpo.

No sistema digestório, temos como barreiras a saliva, a acidez do suco gástrico, a secreção biliar, o muco produzido ao longo do sistema digestório, que funcionam neutralizando ou destruindo possíveis causadores de agressão. Temos, ainda, como outros exemplos, a lágrima, os cílios que recobrem internamente todo o trato respiratório, o líquido que lubrifica naturalmente a vagina e a urina.

Desde que nossas funções orgânicas estejam em equilíbrio, as barreiras inespecíficas impedem uma série de infecções sem que haja necessidade do envolvimento da imunidade celular ou humoral.

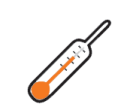

Se tiver interesse em saber mais sobre como funcionam essas barreiras, indicamos:

STITES, D. P.; TERR, A. I. Imunologia básica. Rio de Janeiro: Guanabara-Koogan, 2010. 187 p.

Humoral refere-se à resposta imunológica realizada pelas moléculas existentes no plasma sanguíneo, os anticorpos. Mais adiante, neste capítulo, abordaremos um pouco o funcionamento deste tipo de defesa imunológica. 
Figura 1 - Barreiras imunológicas

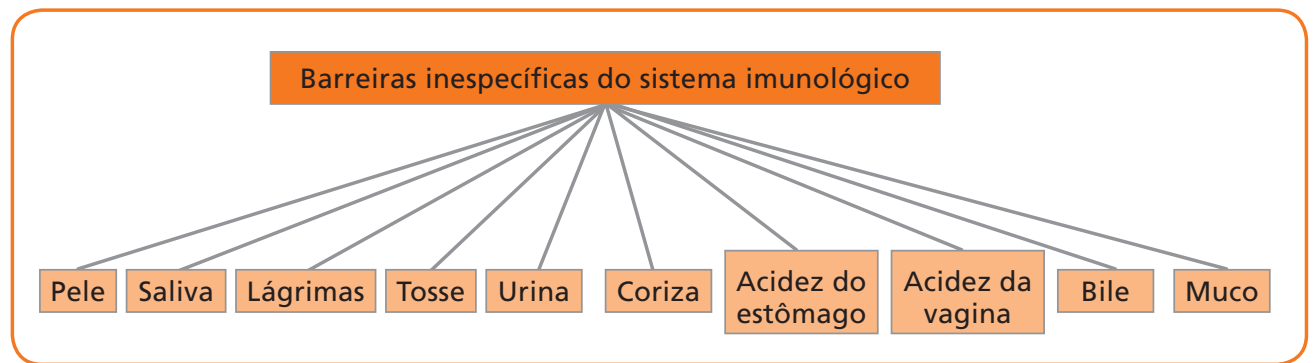

\section{As barreiras específicas}

Tais barreiras são mais complexas, e seu acionamento se dá mediante condições especiais que tentaremos simplificar. A primeira informação importante para compreender as barreiras específicas é saber que elas são desencadeadas por um estímulo. Esse estímulo ocorre pelo contato do nosso organismo com um antígeno, ou seja, com um elemento ou substância capaz de provocar a resposta imunológica.

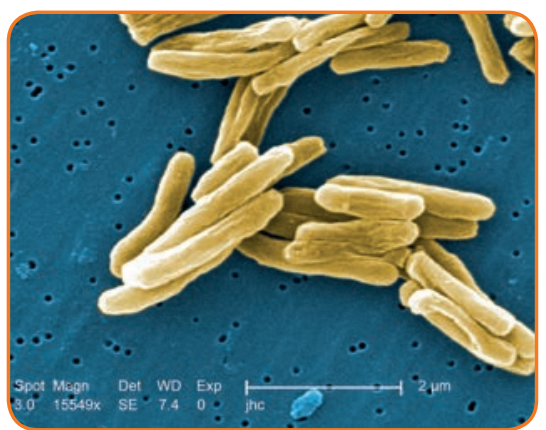

Mycobacterium tuberculosis

Fonte: Phil, CDC.

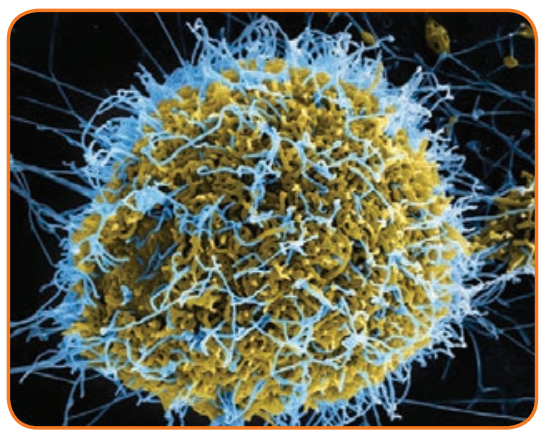

Vírus Ebola

Fonte: Niaid.

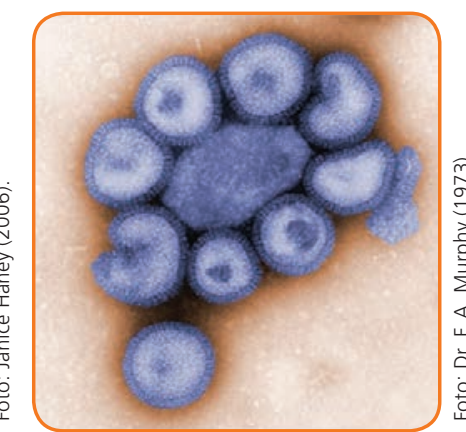

Vírus Influenza

Fonte: Phil, CDC.

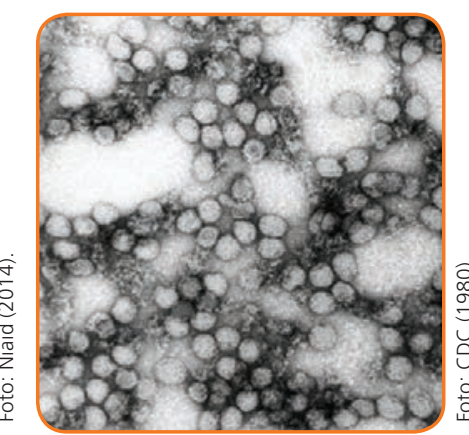

Vírus Febre Amarela Fonte: $C D C$.

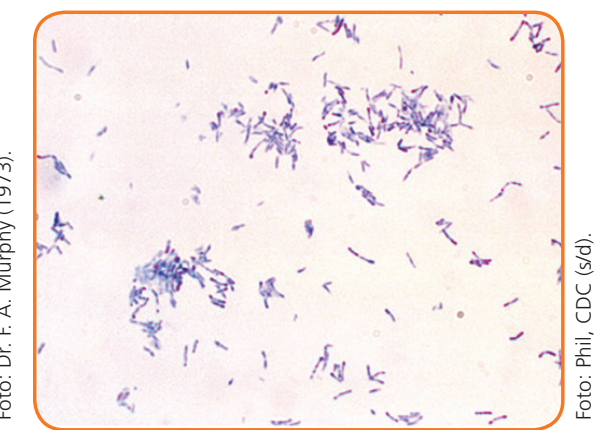

Corynebacterium diphtheriae Fonte: Phil, CDC.

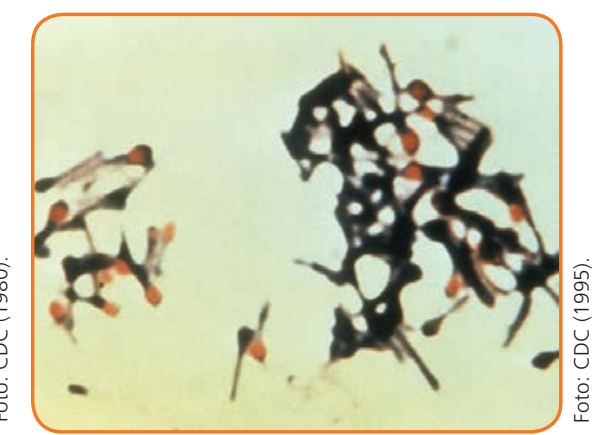

Clostridium tetani

Fonte: $C D C$.

Antígenos são microrganismos ou substâncias capazes de desencadear uma resposta imunológica ao entrar em contato com o organismo. Podem ser elementos presentes em vírus, bactérias, fungos, macromoléculas (como veneno das serpentes) etc. 
Essa resposta irá ocorrer com a formação de anticorpos, que são as imunoglobulinas. As imunoglobulinas são proteínas especializadas, divididas em cinco classes:

1. A imunoglobulina A (IgA) encontra-se presente nas secreções, como leite materno, muco, lágrimas, suor, saliva, colostro, secreção vaginal e secreção intestinal. IgA é importante na imunidade local (de mucosa), protegendo o organismo das infecções que ocorrem através da penetração de microrganismos pela mucosa do trato respiratório ou do trato gastrintestinal.

2. A imunoglobulina D (IgD) é encontrada na forma de receptor em uma das células de defesa que compõem o nosso sistema imunológico, o linfócito B. Sua função é promover a ativação do linfócito B através da ligação com o antígeno na superfície da célula, sinalizando a necessidade de se desencadear uma resposta de defesa do organismo. A partir daí o linfócito B virgem (ou seja, aquele que está sendo estimulado pela primeira vez) se diferencia em outro tipo de célula, o plasmócito, capaz de secretar, no plasma, a imunoglobulina específica contra aquele antígeno agressor, a IgM.

3. A imunoglobulina $M$ (IgM) está presente nos primeiros dias de infecção por até em média 15 a 21 dias, com pico entre 5 e 14 dias de infecção. Em alguns casos, sua presença se prolonga por até 2 meses. Está diretamente relacionada a infecções ou reações recentes à presença de substâncias nocivas (por exemplo, picada de aranha).

4. A imunoglobulina G (IgG) circula no sangue a partir do segundo contato das células de defesa com um antígeno, com pico médio entre duas ou oito semanas. Assim, sua presença na corrente sanguínea indica contato prévio com determinado antígeno, uma resposta ligada a reações antigas e memória imunológica. É a única classe de imunoglobulina que atravessa a placenta, fazendo uma imunização passiva do recém-nascido. Encontra-se presente também no leite materno, porém em quantidades menores que a IgA.

5. A imunoglobulina E (IgE) possui relevante papel na imunidade, mas não se relaciona diretamente com a imunização. Encontra-se ligada às reações alérgicas e à destruição de organismos parasitas em infestações, sendo responsável pela neutralização do verme que será destruído pelos eosinófilos.

A resposta imunológica nada mais é que a geração de anticorpos mediante a introdução, no organismo, de elementos nocivos que tenham a capacidade de estimular e provocar o sistema imune. A imunização, por sua vez, consiste na produção de anticorpos específicos, após a inoculação
Receptor refere-se a uma molécula disposta na membrana de uma célula e que é capaz de "ligar" outras moléculas, desencadeando processos bioquímicos e fisiológicos. No exemplo que demos, a IgD é esse receptor, o qual, interagindo com o antígeno, ativa mudanças no linfócito $B$.

Eosinófilo é um tipo de célula que, quando ativada, libera grânulos que são tóxicos aos microrganismos invasores. 
Imunoglobulinas homólogas são aquelas conferidas por anticorpos obtidos do plasma de seres humanos.

Imunoglobulinas heterólogas, também conhecidas como soros, são conferidas por anticorpos obtidos do plasma de animais previamente vacinados.
Soros heterólogos e homólogos serão abordados no Capítulo 2, "O calendário de vacinação brasileiro e as estratégias para imunização da população", do livro Rede de Frio: gestão, especificidades e atividades (SILVA; FLAUZINO, 2016). do antígeno artificial próprio (vacina), nos prazos adequados, estabelecidos nos calendários vacinais, ou é adquirida naturalmente através de infecção por microrganismo.

\section{Classificação da imunidade}

Para fins didáticos, visando facilitar o entendimento, a imunidade pode ser organizada nas seguintes categorias:

\section{Quanto à sua produção}

a) Imunidade passiva: pode ser obtida naturalmente, através da via placentária e/ou da amamentação, ou artificialmente pela administração de anticorpos específicos, como as imunoglobulinas homólogas ou heterólogas, por exemplo, imunoglobulina contra hepatite B e soro antidiftérico, respectivamente.

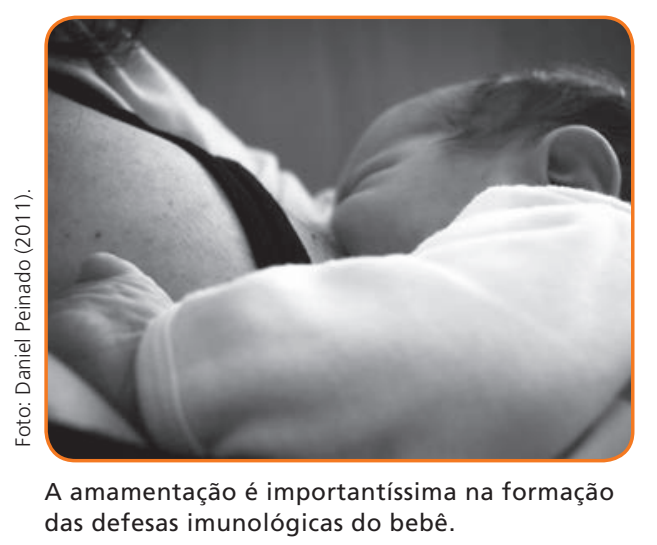

Outra forma de produzir imunização passiva é a utilização de soros. Eles são produtos imunobiológicos indicados para quem necessita de uma imunidade protetora contra certas doenças infecciosas, ou para neutralizar toxinas ou venenos de forma mais rápida. Os soros já são anticorpos prontos (imunoglobulinas, a maioria da classe IgG). São obtidos de humanos (imunoglobulinas de origem humana ou soro homólogo), ou de outras espécies animais (soros heterólogos), sendo atualmente utilizados equídeos, por seu grande porte e facilidade de manejo. O tipo de imunização induzida pelo soro é chamado de passiva artificial.

Os soros, diferente da imunização ativa artificial (vacinas), não induzem memória imunológica, motivo pelo qual, quando catabolizados, o indivíduo volta a se tornar suscetível. A durabilidade da proteção varia de acordo com as condições de saúde de quem o recebe, sendo que a proteção, diferente das vacinas, é transitória.

b) Imunidade ativa: obtida por produção de anticorpos específicos pelo organismo, após a introdução do agente nocivo por contato 
resultante de infecção, inoculação acidental ou através de vacinas próprias para conferir a imunização que se deseja alcançar.

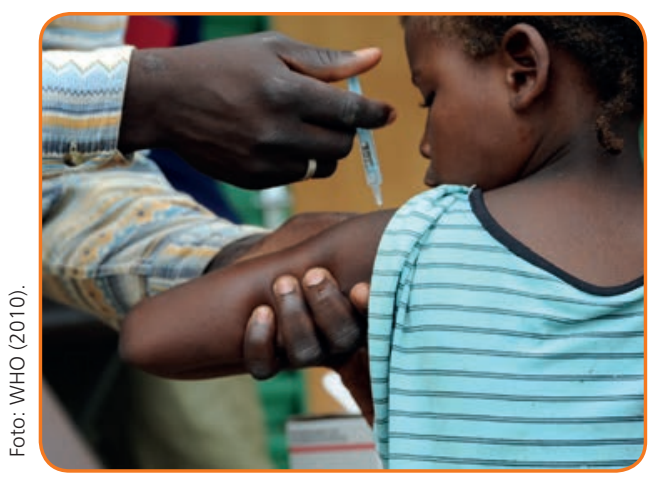

Imunização por meio de vacinas.

Ainda sobre imunidade ativa, existe também a imunidade de rebanho. Isso diz respeito ao fato de que crianças não vacinadas podem desenvolver anticorpos específicos sem receber diretamente a vacina, mas tendo contato com o vírus atenuado expelido via oral ou fecal por uma criança devidamente vacinada. Esse contato resulta em redução do número de doentes e da chance de transmissão de seus agentes causadores, protegendo indiretamente aqueles que não tiveram acesso à vacinação. Dessa forma, toda a comunidade poderá se beneficiar. A vacina oral pólio retrata o melhor exemplo desse fato. É por esse motivo que se recomenda, nas campanhas de vacinação da poliomielite, que mesmo as crianças já vacinadas com esquema completo recebam novamente a vacina, para que possam contribuir para a disseminação do vírus vacinal no ambiente.

Figura 2 - Imunidade de rebanho

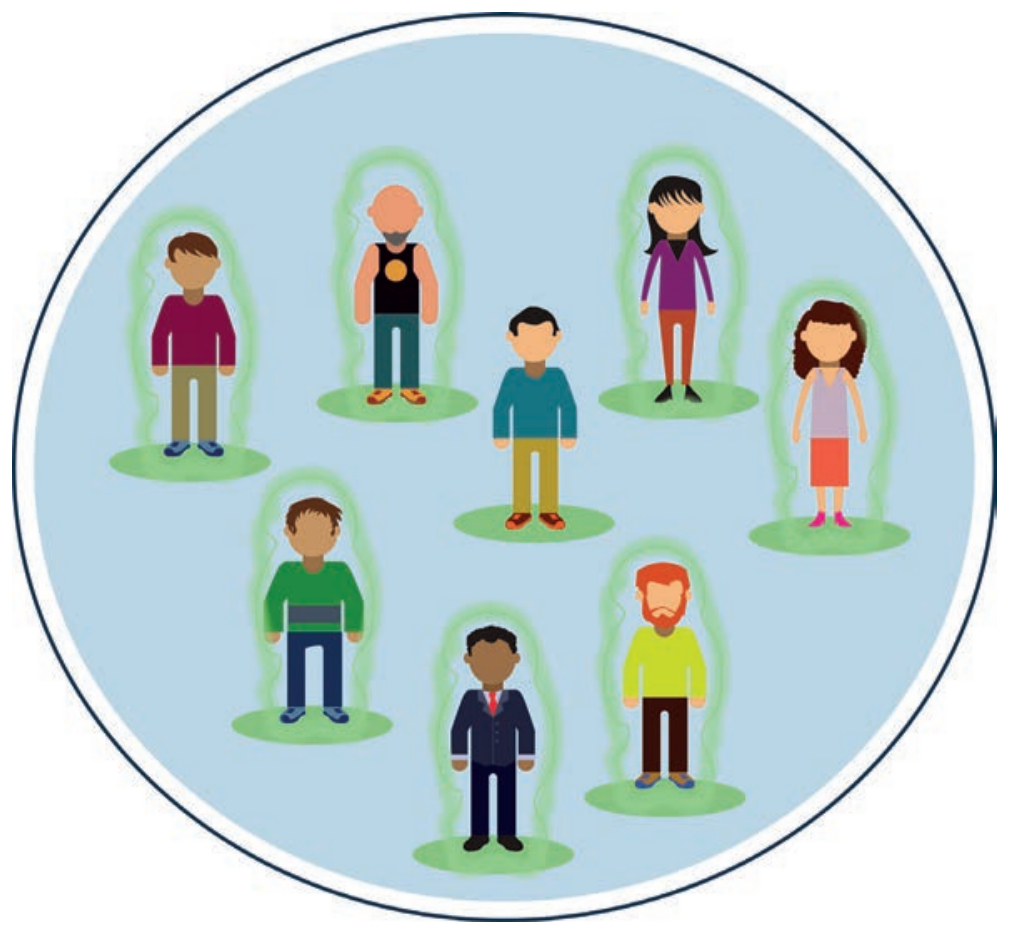

Outros conceitos associados ao de imunidade de rebanho, como cobertura vacinal, vacinação de bloqueio etc., são importantes para se compreender como funciona o sistema imunológico quando exposto a essas estratégias, assim como outras ações desenvolvidas no controle/ eliminação das doenças preveníveis por imunização, temas desta publicação. 
Todo produto comercializado para uso farmacológico em humanos necessita ser desenvolvido por meio de estudos, com protocolos rigorosos, que passam por algumas fases de testes; a fase de segurança e eficácia é denominada Fase III.
Leucócitos polimorfonucleares são também conhecidos como granulócitos; incluem os neutrófilos, eosinófilos e basófilos.

\section{Importante!}

Além dos fatores individuais e da capacidade de cada ser humano para desenvolver imunidade, a introdução bem-sucedida de vacinas em programas de imunização depende, também, de outros fatores, sendo os principais a segurança e a eficácia da vacina.

Durante as fases de teste de uma vacina, em um ambiente ideal, avalia-se:

- a segurança da vacina, ou seja, com que dose o indivíduo vacinado virá apresentar uma resposta imunológica duradoura, com efeito protetor máximo e o mínimo de eventos adversos pós-vacinais;

- a eficácia, ou seja, num grupo de indivíduos vacinados, qual proporção apresentou confirmação laboratorial, medida pela quantidade de anticorpo produzido circulante no sangue, tornando-se, então, imune ao patógeno cuja infecção se pretende prevenir. A eficácia esperada de uma vacina deve ser em torno de $90 \%$ a 95\%. É esse o percentual recomendado para garantir proteção aos indivíduos vacinados e, também, os não vacinados, gerando imunidade de rebanho.

\section{Quanto aos agentes que geram resposta imunológica no organismo}

A imunidade natural e a adquirida são formas diferentes de respostas imunológicas contra agentes microbianos. A imunidade natural ou inata foi incorporada ao nosso patrimônio imunológico ao longo de milhões de anos de evolução biológica. A resposta anti-infecciosa da imunidade inata envolve elementos (como proteínas de fase aguda, do sistema complemento e citocinas) e células (monócitos, macrófagos, granulócitos, linfócitos NK e células dendríticas) e apresenta a característica de permanecer inalterada em encontros sucessivos com o mesmo antígeno, ao contrário da imunidade adquirida. Quando a imunidade natural não é suficiente para a eliminação dos antígenos, são acionados outros mecanismos imunológicos que visam criar defesa específica contra o microrganismo invasor.

A imunidade adquirida apresenta especificidade para antígenos e memória imunológica. A especificidade é exercida através de anticorpos (imunidade humoral) e células programadas para combater antígenos específicos (imunidade celular). A imunidade humoral e a celular tratam de diferentes funções do sistema linfoide:

a) imunidade humoral: trata da resposta imunológica realizada por moléculas existentes no plasma sanguíneo, ou seja, por anticorpos produzidos pelos linfócitos B.

b) imunidade celular: traduz a capacidade da resposta imunológica mediada por células como linfócito T, macrófagos, leucócitos 
polimorfonucleares e outras células da imunidade inata, que realizam fagocitose de antígenos e que, ao serem ativadas pelo antígeno, reconhecem antígenos livres na superfície.

Quadro 1 - Síntese dos diferentes tipos de produção de imunidade

\begin{tabular}{|l|l|l|}
\hline Imunidade & Passiva (exemplos) & Ativa (exemplos) \\
\hline Natural & Amamentação & Infecção \\
\hline Adquirida & Administração de soro & Imunização \\
\hline
\end{tabular}

Como você deve estar percebendo, o sistema imunológico é complexo e envolve um conjunto de moléculas e células, cada uma com características e funções específicas no processo de defesa do organismo.

Como a ideia deste capítulo é trazer apenas uma visão geral para você, profissional da rede de frio, sobre como se dá a imunização de um indivíduo por meio da vacinação, não vamos abordar de forma mais detalhada esses componentes. Produzimos, então, dois anexos para este capítulo, de forma a contribuir um pouco mais para o aprofundamento do tema, caso sinta necessidade.

- Anexo A - Glossário de alguns termos de imunologia relacionados ao capítulo

- Anexo B - Processo de imunidade celular

Além disso, indicamos que consulte a seguinte bibliografia:

- STITES, D. P.; TERR, A. I. Imunologia básica. Rio de Janeiro: GuanabaraKoogan, 2010. 187 p.

\section{Vacinas, soros e imunização}

Com base numa compreensão geral de como funciona o sistema imunológico, podemos passar agora à discussão sobre como a vacina atua no organismo.

Como apresentado no capítulo anterior, vacinas são preparações que contêm microrganismos vivos ou mortos ou suas frações (FUNDAÇÃO NACIONAL DE SAÚDE, 2001). São antígenos capazes de induzir, em um indivíduo, a imunidade ativa e específica contra um microrganismo. Geralmente oferecem proteção duradoura, algumas por toda a vida.

As vacinas podem conter um (por exemplo, BCG) ou mais antígenos (por exemplo, DTP, pentavalente, poliomielite). As que possuem dois ou mais antígenos são denominadas vacinas combinadas. Existem, ainda, as vacinas conjugadas, que apresentam dois ou mais produtos
Fagocitose de antígenos é a destruição destes por envolvimento e degradação por enzimas. 
associados em sua composição. As conjugadas são produzidas quando o patógeno não possui uma molécula imunologicamente potente, como é o caso de polissacarídeos do Haemophilus influenzae (Hib). Para gerar imunidade para Hib, é necessário conjugar o polissacarídeo com outro composto que seja imunologicamente mais potente, como uma proteína toxoide tetânica, por exemplo.

Assim como uma infecção natural com um antígeno, as vacinas são capazes de produzir memória imunológica.

\section{Memória imunológica}

Quando o organismo entra em contato com um antígeno, ocorre a produção de imunoglobulina M (IgM), para combater o agressor, e, também, de lgG, para formar uma memória contra ele. No caso de um segundo contato, o organismo será capaz de gerar uma resposta mais rápida e mais intensa, em decorrência da memória arquivada e do acionamento imediato do sistema imune.

Isso significa que, ao entrar em contato com o antígeno pela segunda vez, já existe uma população de linfócitos B capazes de reconhecer esse antígeno, em virtude das células de memória geradas na resposta primária. Tanto na primeira infecção quanto na segunda, há a produção dos anticorpos IgM e IgG, porém, na resposta primária, IgM é a principal imunoglobulina, e a produção de IgG é menor e mais tardia. Na resposta secundária, a IgG é a imunoglobulina predominante. Nas duas respostas, a concentração de IgM no plasma diminui rapidamente, de maneira que, após uma ou duas semanas, observa-se queda acentuada, enquanto a produção de IgG é persistente. Nesse segundo contato com o antígeno, a produção de anticorpos é mais rápida, e são atingidos níveis mais elevados.

Quadro 2 - Resposta imunológica para infecções primárias e secundárias

\begin{tabular}{|l|l|}
\hline $\begin{array}{l}1^{\circ} \text { contato com o antígeno } \\
\text { Imunidade natural ou vacinação }\end{array}$ & $\begin{array}{l}2^{\circ} \text { contato com o antígeno } \\
\text { Imunidade natural }\end{array}$ \\
\hline $\begin{array}{l}\text { Produção de células de memória imunológica } \\
\text { (linfócitos B) }\end{array}$ & $\begin{array}{l}\text { População de linfócitos B capazes de } \\
\text { reconhecer o antígeno }\end{array}$ \\
\hline Produção alta e rápida de IgM & Produção alta e rápida de IgG \\
\hline Produção menor e tardia de IgG & Produção menor de IgM \\
\hline
\end{tabular}

Para facilitar a compreensão, podemos fazer uma metáfora: na primeira infecção (natural ou por vacinação), o anticorpo é "esculpido", "criado", enquanto na segunda o "molde" já existe, e o processo é de produção de réplicas da "escultura” já existente. 
As vacinas induzem uma imunidade duradoura, como os toxoides, por cerca de 10 anos, e as virais atenuadas, como o sarampo e a rubéola, provavelmente por toda a vida. A pessoa que está em dia com sua vacinação, e apresenta o registro oficial das doses aplicadas, é considerada imune às doenças contra as quais foi vacinada. Então, pressupõe-se que, após uma exposição ao agente infeccioso específico, estará protegida contra a doença, pois já possui os anticorpos protetores. Sendo assim, não precisa receber vacina nem soro.

Ao contrário, quando a situação vacinal é desconhecida ou incompleta, há necessidade de vacinação com esquema completo (ou seja, de refazer todas as doses), pois as pessoas que não apresentam o registro oficial das doses aplicadas são consideradas não vacinadas. Geralmente isso ocorre por perda do cartão.

Para as pessoas que apresentam o registro, mas cujas doses necessárias ainda não se completaram, basta completar as doses que faltam. Nesses casos, geralmente, não há necessidade de recomeçar o esquema vacinal, pois o sistema imunológico guarda a memória das doses aplicadas anteriormente.

Dependendo da gravidade da ocorrência, muitas vezes, existe a necessidade de se associar a vacinação e o soro específico, pois a vacina demora de 14 a 21 dias, em média, para produzir anticorpos protetores, e o soro, como já possui imunoglobulinas prontas, irá proteger a pessoa, temporariamente, até que a ação da vacina se inicie. É mais ou menos assim: quando a ação do soro está terminando, começa a da vacina. Exemplos mais comuns são os casos de profilaxia da raiva, do tétano, da difteria e da hepatite B.

Outra situação é a imunização contra acidentes por animais peçonhentos e por botulismo, para o qual não existe vacina, só o soro. Nesse caso, quando a pessoa se cura, pode ficar vulnerável, novamente, diante de outra exposição ao agente.

\section{Considerações finais}

Podemos perceber, ao finalizar este capítulo, o quanto se faz importante conhecer sobre a imunidade, seus componentes e mecanismos de ação. Ao estar ciente dessas ações, você, trabalhador da rede de frio, terá condições de compreender que o objetivo de administrar um imunobiológico em um organismo é que este o reconheça e responda, produzindo anticorpos e gerando proteção. E para que isso ocorra, é necessário que toda a cadeia de rede de frio funcione perfeitamente para que a estrutura do imunobiológico esteja plenamente preservada!

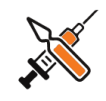

É importante guardar o registro de vacinação, pois a conduta vacinal a ser adotada no futuro depende dele. 


\section{Referências}

BARATA, P. C. R.; LEAL, M. C. Distribuição etária do sarampo e vacinação: considerações sobre alguns dados do município do Rio de Janeiro. Cadernos de Saúde Pública, Rio de Janeiro, v. 1, n. 1, jan./mar. 1985.

CENTERS FOR DISEASE CONTROL AND PREVENTION. Principles of vaccination: epidemiology and prevention of vaccine-preventable diseases. 11. ed. Washington, DC: Public Health Fundation, 2009. p. 1-8.

FARHAT, C. K. et al. Bases imunológicas. In: FARHAT, C. K. et al. Imunizações: fundamentos e prática. 4. ed. São Paulo: Atheneu, 2000. p. 19-36.

FUNDAÇÃO NACIONAL DE SAÚDE (Brasil). Manual de normas de vacinação. 3. ed. Brasília, DF, 2001.

KREBS, L. S. et al. Definições em imunizações. In: CUNHA, J.; KREBS, L. S.; BARROS, E. Vacinas e imunoglobulinas. Porto Alegre: Artmed, 2009. p. 167-179.

MACEDO, C. G. The role of prevention in health and public health: challenges for the future. In: PAN AMERICAN HEALTH ORGANIZATION. Vaccines. Washington, DC, 2003. p. 321-324.

MERCK. Manual MSD: edição de saúde para a família. Ed. portuguesa. New Jersey, 2009. Disponível em: <http://www.manualmerck.net>. Acesso em: 15 set. 2015.

SASSON, S.; SILVA Jr., C. Biologia celular. 5. ed. Rio de Janeiro: Saraiva, 2011.

SILVA, M. N.; FLAUZINO, R. F. (Org.). Rede de frio: gestão, especificidades e atividades. Rio de Janeiro: Ed. Fiocruz, 2016. No prelo.

STITES, D. P.; TERR, A. I. Imunologia básica. Rio de Janeiro: Guanabara-Koogan, 2010.

UNICAMP. Faculdade de Ciências Médicas. Imunologia celular: overview. Campinas, [2016?]. Disponível em: <http://www.fcm.unicamp.br/fcm/en/cipoi/imunologia-celular/overview>. Acesso em: 22 set. 2016.

ZAGO, M. A.; FALCÃO, R. P.; PASQUINI, R. Tratado de hematologia. São Paulo: Atheneu, 2013. 


\section{Anexo A - Glossário de alguns termos de imunologia relacionados ao capítulo}

\section{Antígeno}

"Substância orgânica nociva, de natureza geralmente proteica, que, inoculada no organismo, provoca como reação a produção de anticorpos específicos" (MICHAELIS, 2015).

\section{Anticorpo}

Também denominado imunoglobulina, é uma substância específica de origem celular (produzida por um tipo celular denominado plasmócito) que torna inócuas as substâncias orgânicas capazes de produzir moléstias, quando introduzidas no organismo (MICHAELIS, 2015).

\section{Célula dendrítica}

Células dendríticas são células de forma estrelada ou em forma de árvore (do grego dendron, "árvores") encontradas em órgãos linfoides ou imunológicos e nas interfaces entre nosso corpo e o meio ambiente, que são especializadas na captura e apresentação de antígenos para os linfócitos. A camada epidérmica da pele tem uma rica rede de células dentríticas. Elas revestem também as superfícies das vias aéreas e do intestino, onde funcionam como sentinelas (CRUVINEL et al., 2010; ROCKEFELLER UNIVERSITY, 2015).

\section{Citocina}

Citocinas são pequenas proteínas secretadas pelas células. Têm um efeito específico sobre as interações e comunicações entre as células.

Citocina é um termo geral. Outros nomes incluem linfocina (citocina feita por linfócitos), monocina (citocina produzida por monócitos), quimiocina (citocina com atividade quimiotática) e interleucina (citocina produzida por um leucócito que atua sobre outros leucócitos).

As citocinas podem atuar sobre as células que as secretam (ação autócrina) e sobre as células próximas (ação parácrina), ou, em alguns casos, sobre células distantes (ação endócrina). As principais são as interleucinas (IL, numeradas sequencialmente de 1 a 35), os interferons (IFN $\alpha, \beta$ e $\gamma$ ), os fatores estimulantes de colônias (CSF), o fator de necrose tumoral (TNFl $\alpha$ e TNF2 $\beta$ ) e o fator de transformação do crescimento (TGFß) (SHANG; AN, 2009). 


\section{Componentes do sistema imunitário}

O sistema imunitário é composto por células e substâncias solúveis. As células mais importantes do sistema imunitário são os glóbulos brancos. Os macrófagos, neutrófilos e linfócitos são tipos diferentes de glóbulos brancos. As substâncias solúveis são moléculas que não fazem parte das células, mas que se dissolvem num líquido como o plasma. As substâncias solúveis mais importantes são os anticorpos, as proteínas do sistema do complemento e as citocinas. Algumas substâncias solúveis atuam como mensageiras para atrair e ativar outras células. O complexo de histocompatibilidade maior (MHC, major histocompatibility complex) é a base do sistema imunitário e ajuda a identificar o que é próprio e o que é estranho. Contém um conjunto de genes que codificam proteínas expressas na membrana das células e que são responsáveis pelo reconhecimento e apresentação do antígeno e pela rejeição de transplantes (MERCK, 2009; BYOIN, 2009).

\section{Fagocitose}

Processo pelo qual uma célula envolve uma partícula com seu próprio corpo, e a partícula acaba ficando no interior de seu citoplasma (MICHAELIS, 2015).

\section{Linfócitos natural killer}

Os linfócitos natural killer (NK), do inglês natural killers, "matadores naturais", representam a primeira linha de defesa contra as células infectadas por vírus e as células tumorais. O papel das células NK em respostas imunes tem sido explorado marcadamente, principalmente, em virtude da identificação de receptores de células NK e os seus ligantes, mas também pela análise dos mecanismos subjacentes aos efeitos de diversas citocinas sobre o desenvolvimento e a função das células NK. A população de linfócitos, que compartilha a função e os receptores com as células NK, é representada por células T natural killer (NKT). Os linfócitos NKT são reguladores de ambos os tipos de resposta imune - inata e adaptativa -, mas também têm sido relatados funcionando como células efetoras antitumorais (PAPAMICHAIL, 2003).

\section{Linfonodos}

Linfonodos são órgãos corporais (não glândulas) espalhados pelo nosso corpo. Têm a função de filtrar para fora todas as bactérias mortas, vírus e outros tecidos mortos, a partir do fluido linfático, e eliminá-los do corpo. Eles também são o lugar onde os glóbulos brancos (linfócitos) gastam muito do seu tempo. Quando o sistema imunitário é ativado, 
ocorre a produção de um grande número de linfócitos, tornando-os dolorosos e aumentados de tamanho (NHL CYBERFAMILY, 2016).

\section{Sistema complemento}

Em imunologia, é um sistema complexo de mais de 30 proteínas que atuam em conjunto para auxiliar na eliminação de microrganismos infecciosos. Especificamente, o sistema complemento causa a lise (a desintegração de uma célula pela rotura da parede ou membrana celular) das células estranhas e infectadas, a fagocitose (ingestão) de partículas estranhas e detritos e a inflamação do tecido circundante (ENCICLOPÆDIA BRITANNICA, 2015).

\section{Referências}

BYOIN, Matsunami Sogo. The immune system. New England Journal, 2009 Feb. 3. Disponível em: <http://www.nejm.org>. Acesso em: 30 jul. 2016.

CRUVINEL, W. M. et al. Sistema imunitário, parte 1: fundamentos da imunidade inata com ênfase nos mecanismos moleculares e celulares da resposta inflamatória. Revista Brasileira de Reumatologia, São Paulo, v. 50, n. 4, p. 434-461, 2010.

ENCICLOPAEDIA BRITANNICA. Complement. Chicago, [2015]. Disponível em: <http://global. britannica.com/science/complement-immune-system-component>. Acesso em: 22 set. 2016.

MERCK. Manual MSD: edição de saúde para a família. Ed. portuguesa. New Jersey, 2009. Disponível em: <http://www.manualmerck.net>. Acesso em: 15 set. 2015.

MICHAELIS. Dicionário brasileiro da língua portuguesa. São Paulo: Melhoramentos, 2015. Disponível em: <http://michaelis.uol.com.br/moderno/portugues/index.php?lingua=portuguesportugues\&palavra=ant\%EDgeno>. Acesso em: 30 jul. 2016.

NHL CYBERFAMILY. Lymph nodes. [S.I., 2016]. Disponível em: <http://www.nhlcyberfamily.org/ nodes.htm>. Acesso em: 30 jul. 2016.

PAPAMICHAIL, M. Natural killer lymphocytes: biology, development, and function. Washington, DC: US National Library of Medicine: National Institutes of Health, 2003.

ROCKEFELLER UNIVERSITY. Laboratory of Cellular Physiology and Immunology. Introduction to dendritic cells. New York, 2015.

SHANG, Jung-Ming; AN, Jianxiong. Cytokines, inflammation and pain. Washington, DC: US National Library of Medicine: National Institutes of Health, 2009. 


\section{Anexo B - Processo de imunidade celular}

A imunidade celular está diretamente ligada às reações de rejeição de órgãos e tecidos nos transplantes, mas também à destruição de microrganismos e corpos estranhos, introduzidos ou que penetrem no organismo. Efetua-se em duas fases: fase de reconhecimento e fase efetora. Os nódulos linfáticos regionais capturam antígenos que foram extraídos dos tecidos em sua área de controle e transportados a eles pela rede linfática.

A fase de reconhecimento ocorre nos linfonodos, que, assim como o baço, são órgãos linfoides secundários. Ocorre, inicialmente, a captura de antígenos que foram transportados pela rede linfática, gerando proliferação celular e liberação de proteínas inflamatórias, ficando os linfonodos doloridos e aumentados, formando o que conhecemos por gânglios ou nódulos.

Para que haja o reconhecimento do antígeno pelo linfócito T, há necessidade de o antígeno ser apresentado pelas células apresentadoras de antígenos (APC), que podem ser macrófagos, células dendríticas ou linfócitos $\mathrm{B}$, através das proteínas do complexo de histocompatibilidade maior. A função do MHC é codificar várias proteínas receptoras que ficam nas membranas das células. Essas proteínas atuam no reconhecimento e na apresentação dos antígenos. Esse grupo genético do MHC nos seres humanos recebeu a denominação de antígenos leucocitários humanos (HLA - do inglês Human leukocyte antigen). 
Figura 1 - Apresentação do antígeno pela célula apresentadora do antígeno ao linfócito T

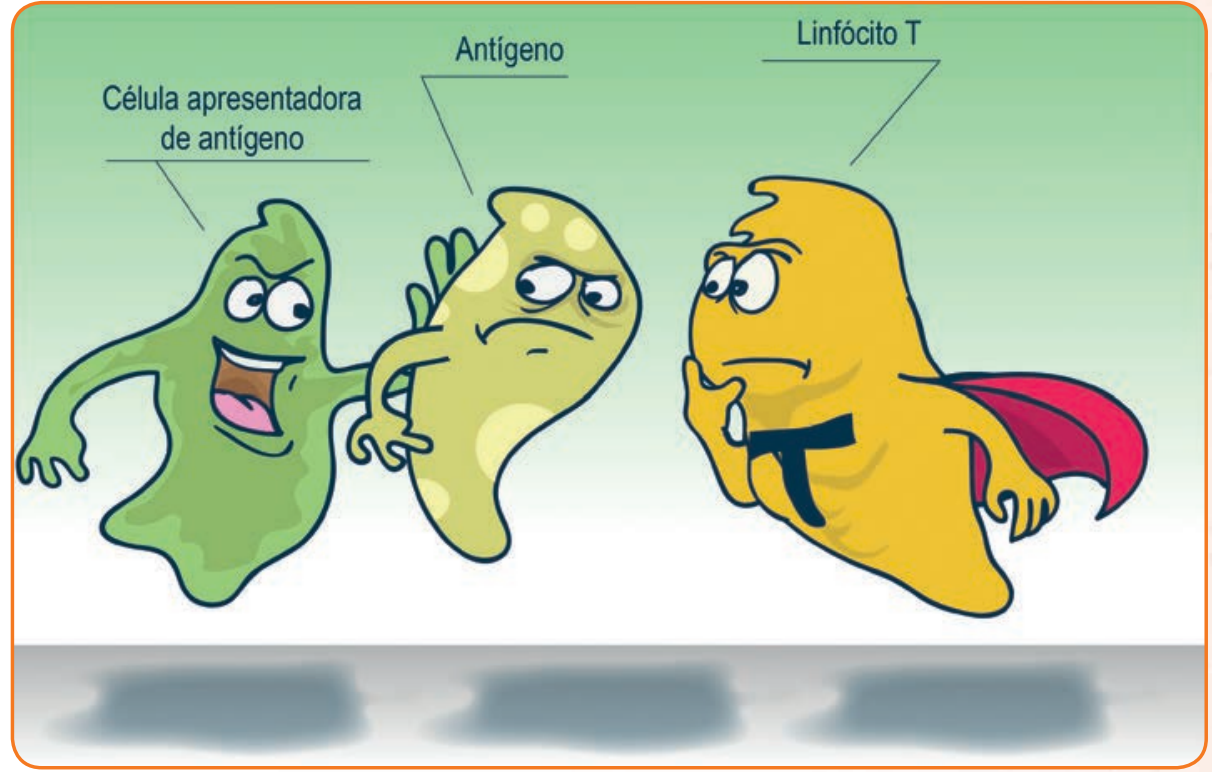

Há três classes de proteínas MHC - classe I, classe II e classe III. Os MHCs de classes I e II apresentam os antígenos às células T. O MHC de classe III não apresenta antígenos, são várias proteínas com funções diferentes no sistema imune, incluindo componentes do sistema de complemento e moléculas envolvidas na inflamação.

O MHC-I sinaliza antígenos de origem intracelular (vírus), enquanto o MHC-II sinaliza antígenos de origem extracelular (bactérias ou células tumorais). Os linfócitos CD-8 interpretam somente sinais recebidos de APC que utilizam o MHC-I, e os linfócitos CD-4 interpretam os sinais recebidos por APC que utilizam o MHC-II. Uma vez estimulados, os linfócitos sofrem uma "explosão clonal”, que é a liberação de fatores de crescimento que irão fazer com que os linfócitos se multipliquem e se capacitem para combater o antígeno. Em síntese:

Linfócitos CD-8 são os linfócitos T citotóxicos; possuem a glicoproteína CD8 na sua superfície, por isso sua denominação.

Linfócitos CD-4 são os linfócitos T auxiliares, também conhecidos como helper; possuem a glicoproteína CD4 na sua superfície.

Figura 2 - Esquema resumindo a fase de reconhecimento

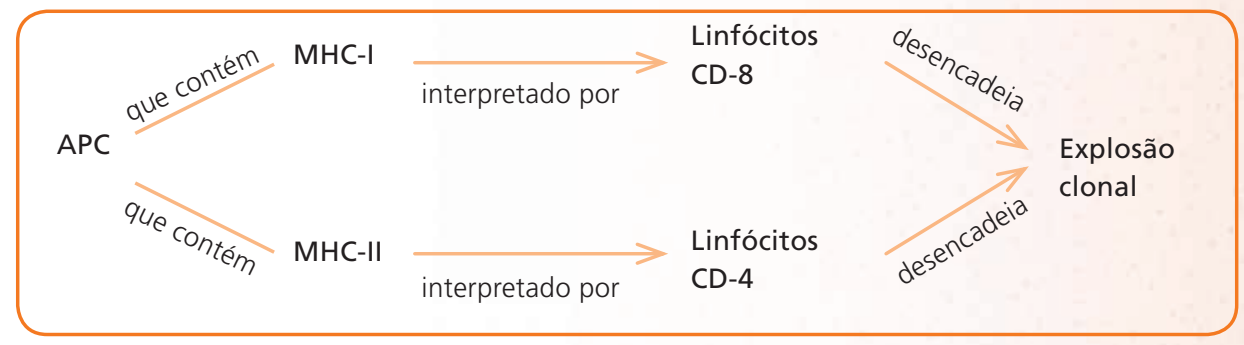

Fonte: Elaboração do autor. 
Ativação de macrófagos significa capacitá-los, deixando sua vida mais longa, com maior poder de destruição do antígeno através de fagocitose.
Na fase efetora, a "expansão clonal" libera citocinas que desencadeiam uma série de mecanismos para combater o antígeno: ativação de macrófagos, de linfócitos B com produção de anticorpos e de linfócitos T-NK. Nessa fase, os anticorpos produzidos pelas células desempenham um papel fundamental na neutralização e eliminação dos microrganismos.

Figura 3 - Esquematização simplificada da resposta imune
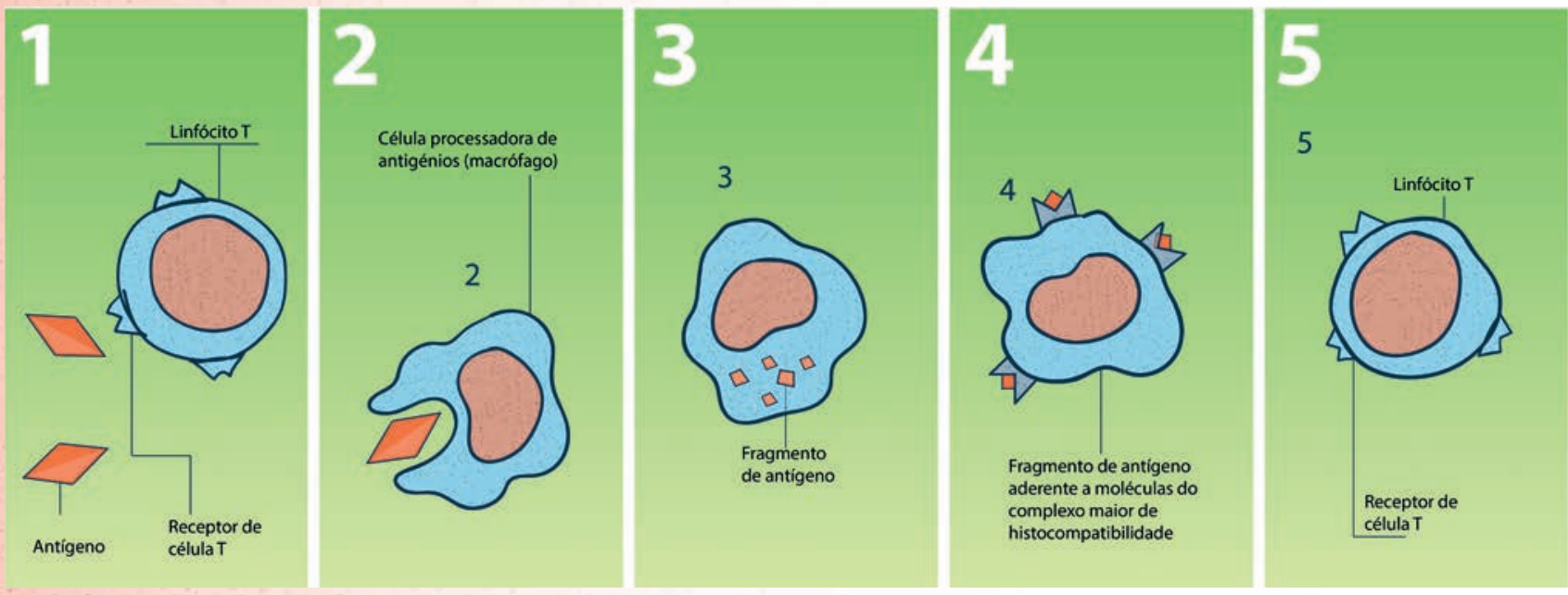

Fonte: Adaptado de p_844.gif (MERCK, 2009).

Papel do Miolo: Offset $90 \mathrm{~g} / \mathrm{m}^{2}$

Papel e Acabamento Capa: Papel Cartão supremo 250g/m²

Ctp Digital: Walprint Gráfica e Editora

Impressão e acabamento: Walprint Gráfica e Editora

Rio de Janeiro, julho de 2017. 